\title{
ASSESSMENT OF THE SORPTION PROPERTIES OF MATERIALS PROPOSED FOR THE CONSTRUCTION OF INSULATION BARRIERS
}

\begin{abstract}
Sorption properties of fine-grain mixtures of mineral waste proposed for construction of separation screens in landfill sites have been examined. The removal of heavy metals by the mixtures analysed was evaluated by the static batch method. It was found that they characterize by high ability to remove heavy metals at the level of over $99 \%$, even with high contents of these elements. The sorption parameters have been determined based on the Langmuir and Freundlich isotherms. The alkaline character of some components of mixtures provides stabilization of $\mathrm{pH}$, preventing removal of heavy metals to the environment in response to contact a barrier with acid solutions.
\end{abstract}

\section{INTRODUCTION}

Since storage in landfills appears to be the most popular method of waste disposal, the waste might represent a serious source of pollution for both soil and water. Therefore, it becomes necessary to separate the polluted areas by means of special purpose separation screens. Conventionally, construction of separation screens involves using synthetic materials (geomembranes) and natural materials which are present in situ in the rock mass. This typically means fine grain clay rock, with granulometric, mineral and chemical compositions that allow obtaining a low filtration coefficient, which is the basic and expected parameter of the screens used for separation. If natural clay rock is unavailable in the location of the storage area, the need arises for obtaining it from other deposits and then transporting it to specified places. Such activities usually cause degradation of the landscape and generation of additional waste of dead rock as well as changes in hydrographic conditions in the area of extraction. Therefore, it seems purposeful to look for the materials which would substitute clay rocks. Since the 90 s of the

${ }^{1}$ Institute of Environmental Engineering, Częstochowa University of Technology, ul. Brzeźnicka 60A, 42-200 Częstochowa, Poland, corresponding author: J. Sobik-Szołtysek, e-mail: jszoltysek@ is.pcz.czest.pl 
last century the possibility of using ashes from the energy industry has been investigated [1]. These wastes were mostly used as an additive improving the parameters of mineral fillers, especially their alkalinity, which has been used for neutralization of acidic effluents. Interaction of polluted waters containing heavy metals with ashes allows their reduction in effluents.

The authors have demonstrated [2] the possibility of using waste mineral materials or by-products from the industry, particularly the components of anthropogenic origins, as their properties allow obtaining a barrier that combines physical separation with chemical activity with respect to various pollutants. In the present work, few types of waste materials (not only fly ash) used for construction of insulation barriers have been examined and described for the first time.

In order to provide a precise characterization of separation properties of mineral materials, it is necessary (due to various physical and chemical processes that occur in these materials) to analyse, apart from the filtration coefficient, some additional parameters, such as mineral composition, diffusion coefficient, sorption parameters and changes in the volume and moisture content [3] as well as filtration/adsorption processes [4]. As demonstrated by Claisse and Ganjian [5], one procedure which is essential for evaluation of usefulness of any material for building separation screens is evaluation their screening ability that in turn necessitates characterization of sorption properties. Heavy metal ions are one of the most toxic inorganic pollutants present in the soil. Some of them are toxic, even at very low concentrations [6,7]. Therefore, the goal of the present study was to determine abilities of removal of selected heavy metals by a model screen based on the anthropogenic components.

\section{EXPERIMENTAL}

Substrate for the analysis. Previous studies of the authors [2] allowed focusing on the following types of materials used for preparation of the mixtures:

- Coal dust (M) sampled from filtration presses in the processing unit of a black coal mine.

- Ashes, i.e. combustion by-products generated by the energy sector during combustion of black coal in conventional and fluidized bed boilers, especially: fly ash from combustion of black coal in conventional boilers (PK), fly ash from combustion of black coal in fluidized bed boilers (PL), and bottom ash from combustion of black coal in fluidized bed boilers (PD).

- Barren rock clay from brown coal deposit in the Bełchatów mine (I).

Materials sampled were air-dried and then 3 mixtures were prepared, varying in the content of components. The main component of each mixture was coal dust $(50 \mathrm{wt}$. \%). The representative specimens were prepared by the quartering method. Their compositions and the filtration coefficients are given in Table 1. 
Table 1

Composition of mixtures

\begin{tabular}{|l|c|c|c|c|}
\hline \multirow{2}{*}{ Mixture } & \multicolumn{2}{|c|}{ Composition [wt. \%] } & \multirow{2}{*}{$\begin{array}{c}\text { Filtration coefficient } \\
{[\mathrm{m} / \mathrm{s}]}\end{array}$} \\
\cline { 2 - 4 } & Coal dust & Ash & Clays & nan $^{-10}$ (unpublished data) \\
\hline MPKI & 50 & $40^{\mathrm{a}}$ & 10 & $7.26 \cdot 10^{-1}$ \\
\hline MPLI & 50 & $40^{\mathrm{b}}$ & 10 & $6.32 \cdot 10^{-10}[2]$ \\
\hline MPD & 50 & $50^{\mathrm{c}}$ & - & $3.0 \cdot 10^{-10}[2]$ \\
\hline
\end{tabular}

${ }^{\mathrm{a}}$ Ash from combustion in conventional boilers.

${ }^{\mathrm{b}}$ Ash from fluidized bed boilers.

${ }^{\mathrm{c} B o t t o m}$ ash.

The mixtures were analyzed in terms of phase composition using X-ray analysis (X-ray diffractometer PANalytical X'PERT PRO-PW 3040/60). The quantitative analysis was performed by the Rietveld method.

Evaluation of cation exchange capacities of the mixtures. Cation exchange capacities (CEC) were determined based on the sorption capacity of methylene blue (MBC). The determination was made according to PN-B-04481:1988P [8]. Cation exchange capacities (CEC) as well as specific surface areas $\left(S_{t}\right)$ were calculated from the equations $[8,9]$ :

$$
\begin{gathered}
\mathrm{CEC}=2.676 \mathrm{MBC} \quad[\mathrm{cmol} / \mathrm{kg}] \\
S_{t}=k \mathrm{MBC} \quad\left[\mathrm{m}^{2} / \mathrm{g}\right]
\end{gathered}
$$

where $\mathrm{MBC}$ is the sorption capacity of methylene blue, $\mathrm{g} / 100 \mathrm{~g}, k$ - the coefficient equal to $20.94 \mathrm{~m}^{2} / \mathrm{g}$.

Static sorption method (batch sorption). Research was done in two stages. The major goal of the first stage of the analysis was determination of optimal conditions (including achieving the equilibrium state) for the sorption process. The impact of the solid to solution ratio (doses of sorbents were: 50,100 and $200 \mathrm{~g} / \mathrm{dm}^{3}$ ) and contact (mixing) time $(0.5,1,2,24 \mathrm{~h})$ on the effectiveness of sorption have been examined. Optimization was carried out for the MPLI mixture. Zinc solutions were prepared by dissolving the appropriate weight of the respective salt $\left(\mathrm{ZnSO}_{4}, \mathrm{ZnCl}_{2}\right)$ in deionized water. The initial concentration of zinc solution was $200 \mathrm{mg} / \mathrm{dm}^{3}$.

Before sorption, due to alkalinizing effect of certain waste components (ash from energy industry) used for preparation of the mixture, the sorbent was washed (mixture MPLI) through mixing with deionized water for $24 \mathrm{~h}$. Then it was dried and used for batch sorption tests. 
In the second stage, batch sorption for all tested mixtures was examined for sorbent dose of $200 \mathrm{~g} / \mathrm{dm}^{3}$ and $24 \mathrm{~h}$ contact time . In this stage, the potential of tested mixtures for heavy metal removal $\left(\mathrm{Zn}^{2+}, \mathrm{Cd}^{2+}, \mathrm{Ni}^{2+}, \mathrm{Co}^{2+}, \mathrm{Cr}^{2+}\right.$ and $\left.\mathrm{Pb}^{2+}\right)$ from aqueous solutions were evaluated. Similar like in first stage of research, concentrations of heavy metals ions in the initial solution were prepared by dissolving the appropriate weight of the respective salt $\left(\mathrm{ZnSO}_{4}, \mathrm{ZnCl}_{2}, \mathrm{CdSO}_{4}, \mathrm{CdCl}_{2}, \mathrm{NiSO}_{4}, \mathrm{NiCl}_{2} \mathrm{CoSO}_{4}, \mathrm{CoCl}_{2}, \mathrm{CrCl}_{2}\right.$, $\left.\mathrm{Pb}\left(\mathrm{NO}_{3}\right)_{2}\right)$ in deionized water. All of salts came from Chempur (Piekary Slaskie, Poland). Initial contents of heavy metals ions in solution used in the experiment in this stage are compared in Table 2.

Table 2

Concentrations of heavy metal ions in aqueous solutions

\begin{tabular}{|c|c|c|c|c|c|}
\hline \multicolumn{6}{|c|}{ Initial concentration of heavy metal ion in solution $\left(\mathrm{mg} / \mathrm{dm}^{3}\right)$} \\
\hline $\mathrm{Zn}^{2+}$ & $\mathrm{Cd}^{2+}$ & $\mathrm{Ni}^{2+}$ & $\mathrm{Co}^{2+}$ & $\mathrm{Cr}^{3+}$ & $\mathrm{Pb}^{2+}$ \\
\hline 10 & 5 & 5 & 0.1 & 10 & 10 \\
\hline 50 & 10 & 10 & 0.5 & 50 & 50 \\
\hline 100 & 50 & 50 & 1 & 100 & 100 \\
\hline 200 & 150 & 150 & 5 & 200 & 200 \\
\hline 500 & 200 & 200 & 10 & 500 & 500 \\
\hline 1000 & 500 & 500 & 100 & 1000 & 1000 \\
\hline
\end{tabular}

All batch experiments were carried out using $200 \mathrm{~cm}^{3}$ glass-stoppered vessels containing $100 \mathrm{~cm}^{3}$ of salts' solution of a known initial concentration of heavy metal ions and weight of the adsorbent. All experiments were performed at room temperature.

The vessels were agitated at a constant speed of $150 \mathrm{rpm}$ for $0.5,1,2,24 \mathrm{~h}$ (in the first stage) and $24 \mathrm{~h}$ (in the second stage) in a shaker (IKA POL HS 260 control) at $298 \mathrm{~K}$. Initial $\mathrm{pH}$ of the solutions was 4.0 and no buffer control of $\mathrm{pH}$ was applied during the adsorption process. Then the solutions were filtered through a filter paper, and the eluates obtained were analysed with regard to the concentrations of tested metals. Concentrations of heavy metals were determined by means of the inductively coupled plasma atomic emission spectroscopy (ICP-OES). $\mathrm{pH}$ in all solutions was measured after sorption.

The equilibrium adsorption capacity $\left(q_{e}\right)$ of heavy metals was calculated from the following equation [10]:

$$
q_{e}=\frac{c_{0}-c_{e q}}{m} \times V \quad[\mathrm{mg} / \mathrm{g}]
$$

The percentage of heavy metals immobilized by the tested mixtures was calculated from [11]: 


$$
\text { Removal }=\frac{c_{0}-c_{e q}}{c_{0}} \times 100 \quad[\%]
$$

where $c_{0}$ is the initial concentration of the ions in the solution, $c_{e q}-$ the equilibrium concentration of the ion in solution, $V$ - the volume of the solution, $m$ - the weight of the sorbent mixture.

The analysis of the experimental data was based on the Freundlich and Langmuir isotherms. The equation of the Langmuir isotherm model can be expressed as [11]:

$$
\begin{gathered}
\frac{c_{e q}}{q_{e}}=\frac{c_{e q}}{q_{m}}+\frac{1}{K_{L} q_{m}} \\
q_{e}=\frac{q_{m} K_{L} c_{e q}}{1+K_{L} c_{e q}}
\end{gathered}
$$

The Freundlich isotherm can be presented in the following form [11]:

$$
\begin{gathered}
\log q_{e}=\log K_{F}+\frac{1}{n} \log c_{e q} \\
q_{e}=K_{F} c_{e q}^{1 / n}
\end{gathered}
$$

where: $q_{m}$ is the maximum adsorption capacity corresponding to the complete monolayer coverage, $\mathrm{mg} / \mathrm{g}, K_{L}, K_{F}$ - the Langmuir constant and the Freundlich constant respectively, $\mathrm{dm}^{3} / \mathrm{mg}, n$ - experimental constant indicative of the adsorption intensity of the sorbent. Adsorption isotherm equation parameters were determined using the STATISTICA (nonlinear estimation test).

Sequential extraction. In order to determine the chemical forms of binding metals by individual phases of the heterogeneous material of the mixtures studied, the adsorbent samples were subjected to the modified sequential analysis according to Tessier et al. [12], who adopted this procedure due to the mineral character of the adsorbent. The extraction procedure has been described in Table 3.

Grain analysis. Evaluation of the effect of the solutions used on durability of screen material was carried out based on the analysis of changes in granulometric composition after reaction with model solutions. Analyses of the article size distribution of the materials tested (before and after sorption) were performed with a laser particle size analyzer LAU-10. 
Procedure of sequential analysis used in the study

\begin{tabular}{|c|c|c|}
\hline Stage & Solvents, conditions of extraction ${ }^{\mathrm{a}}$ & Forms of metals \\
\hline I & $\begin{array}{l}10 \mathrm{~cm}^{3} \text { of } 1 \mathrm{M} \mathrm{MgCl}_{2}, \mathrm{pH}=8.2 \text {, ambient temperature, } \\
\text { contact time } 1 \mathrm{~h}, \text { continuous mixing }\end{array}$ & exchangeable \\
\hline II & $\begin{array}{l}10 \mathrm{~cm}^{3} \text { of } 1 \mathrm{M} \mathrm{CH}_{3} \mathrm{COONa} \text { acidified with } \mathrm{CH}_{3} \mathrm{COOH} \text { to } \mathrm{pH}=7 \text {, } \\
\text { ambient temperature, contact time } 4-5 \mathrm{~h} \text {, continuous mixing }\end{array}$ & bound with carbonates \\
\hline III & $\begin{array}{l}20 \mathrm{~cm}^{3} \text { of } 0.04 \mathrm{M} \mathrm{NH}_{2} \mathrm{OH} \cdot \mathrm{HCl} \text { in } 25 \% \mathrm{CH}_{3} \mathrm{COOH} \text { (vol. \%), } \\
\text { temperature } 96 \pm 3{ }^{\circ} \mathrm{C} \text {, contact time: } 4-5 \mathrm{~h} \text {, periodic mixing }\end{array}$ & $\begin{array}{l}\text { bound with Fe } \\
\text { and Mn oxides }\end{array}$ \\
\hline IV & $\begin{array}{l}3 \mathrm{~cm}^{3} \text { of } 0.02 \mathrm{M} \mathrm{HNO}_{3}+5 \mathrm{~cm}^{3} \text { of } 30 \% \mathrm{H}_{2} \mathrm{O}_{2}, \mathrm{pH}=2, \\
\text { temperature } 85 \pm 2{ }^{\circ} \mathrm{C} \text {, contact time } 2 \mathrm{~h} \text {, periodic mixing } \\
8 \mathrm{~cm}^{3} \text { of } 30 \% \mathrm{H}_{2} \mathrm{O}_{2}, \mathrm{pH}=2 \text {, temperature } 85 \pm 2{ }^{\circ} \mathrm{C}, \\
\text { contact time } 2 \mathrm{~h} \text {, periodic mixing, } 5 \mathrm{~cm}^{3} \text { of } 3.2 \mathrm{M} \mathrm{CH}_{3} \mathrm{COONH}_{4} \\
\text { in } 20 \% \mathrm{HNO}_{3} \text {, ambient temperature, contact time } 0.5 \mathrm{~h} \text {, periodic mixing }\end{array}$ & $\begin{array}{l}\text { bound with organic } \\
\text { matter and sulphides }\end{array}$ \\
\hline V & Mineralization $0.5 \mathrm{~g}$ of residue with $7 \mathrm{~cm}^{3} \mathrm{HNO}_{3}$ & other \\
\hline
\end{tabular}

${ }^{\text {aW }}$ ith respect to $1 \mathrm{~g}$ of dry matter of the mixture.

\section{RESULTS AND DISCUSSION}

\subsection{PHASE MINERAL ANALYSIS}

The phase compositions of the mixtures reflect the characteristics of their components Table 4). The dominant mineral phase in the mixtures was quartz. The MPD mixture

Phase composition of mixtures [wt. \%]

\begin{tabular}{|l|c|c|c|}
\hline \multicolumn{1}{|c|}{ Phase } & MPKI & MPLI & MPD \\
\hline Quartz & 23 & 21 & 45 \\
\hline Mullite & 11 & - & - \\
\hline Anhydrite & - & 8 & 8 \\
\hline Smectite & 20 & 21 & - \\
\hline Kaolinite & 16 & 16 & 15 \\
\hline Illite & 11 & 12 & 13 \\
\hline Chlorite & 8 & 4 & 5 \\
\hline Amorphous matter/coal matter & 11 & 12 & 8 \\
\hline Gypsum & - & 2 & - \\
\hline Piryte & - & $<1$ & 1 \\
\hline Hematite & - & 1 & - \\
\hline Calcite & - & $1-2$ & - \\
\hline Potassium feldspars & - & - & 3 \\
\hline Dolomite & - & - & 1 \\
\hline CaO & - & - & 1 \\
\hline
\end{tabular}


contained approximately twice the quartz in comparison to other mixtures. Minerals from the clay group consist primarily of kaolinite and illite, but due to the presence of clay in the MPKI and MPLI, also significant amounts of smectites were found. The analysis of the MPKI mixture revealed the presence of mullite which is a product of thermal decomposition of kaolinite. The identified share of amorphous matter was similar for all the mixtures. Each mixture contained mineral phases which can be classified as chlorites, but their percentage share is not higher than a few percent. Other found phases especially in the mixtures with ash from fluidised bed reactors are the result of using calcium sorbents in fluidised bed technologies.

\subsection{OPTIMISATION OF THE SORPTION PROCESS}

Washout of MPLI had no effect on adsorption capacity of the mixture. Removal of zinc ions from aqueous solution of zinc chloride and zinc sulfate were $99.96 \%$ and $99.93 \%$, respectively. Due to the lack of difference between the samples washed and not washed, the samples were not washed in further studies.

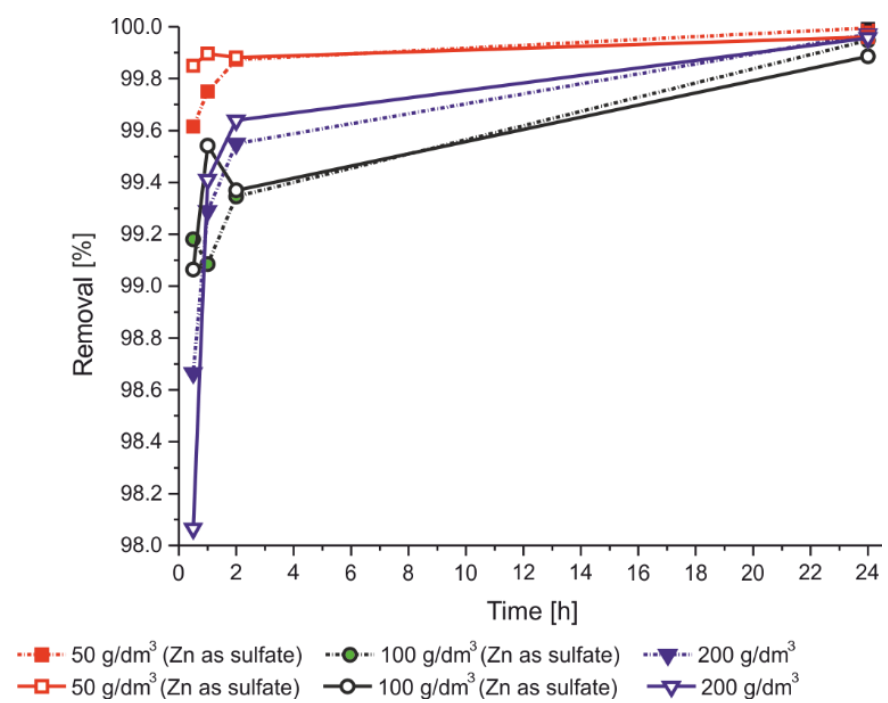

Fig. 1. Effect of contact time on the removal of zinc onto MPLI at various doses of sorbents $\left(50,100\right.$, and $\left.200 \mathrm{~g} / \mathrm{dm}^{3}\right)$, initial zinc concentration $200 \mathrm{mg} / \mathrm{dm}^{3}$

The effects of contact time $(0.5,1,2,24 \mathrm{~h})$ and dose of sorbents $\left(50,100\right.$, and $\left.200 \mathrm{~g} / \mathrm{dm}^{3}\right)$ are shown in Fig. 1. The highest removal of zinc ions for both tested salts was obtained for $200 \mathrm{~g} / \mathrm{dm}^{3}$ of sorbent and mixing time of $24 \mathrm{~h}$, such conditions being used in the batch test in further experiments. 


\subsection{SORPTION CAPACITY}

Figure 2 illustrates the specific surface areas, sorption capacity (MBC), cation exchange capacity (CEC, Eq. (1)) of the mixtures (MPKI, MPLI, MPD).

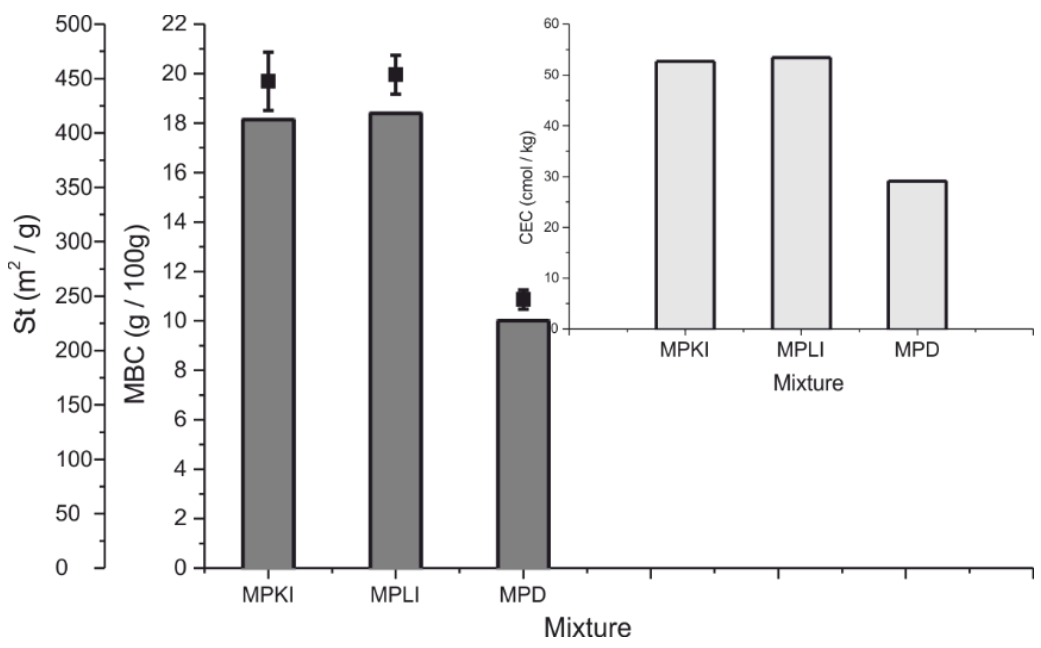

Fig. 2. Sorption capacity (MBC), cation exchange capacity (CEC) and specific surface area (St) of mixtures used in the study

The specific surface areas ranged from 227 to $417 \mathrm{~m}^{2} / \mathrm{g}$, with the highest values observed for MPLI and the lowest for MPD. The sorption capacity ranged from 10.87 to $19.96 \mathrm{~g} / 100 \mathrm{~g}$ d.b. $^{2}$, whereas CEC values were from 29.08 to $53.41 \mathrm{cmol}(+) / \mathrm{kg}$. Since the materials studied are heterogeneous mixtures, their properties result from compilation of the properties of individual components. According to the literature data, the values of specific surface area and sorption capacity for natural mineral sorbents such as clay range from 10 to $800 \mathrm{~m}^{2} / \mathrm{g}$ [13] and from 0.27 to $57 \mathrm{mg} / \mathrm{g}$ [14], respectively. With regard to fly ashes, the authors obtained the values of specific surface area of $0.25-0.45 \mathrm{~m}^{2} / \mathrm{g}$ [15], whereas this value for coal dust is $73 \mathrm{~m}^{2} / \mathrm{g}$. Analysis of the results leads to the conclusion that the mixtures studied are the materials with well-developed specific surface area, which is connected with their fine-grain composition and presence of a number of porous and spherical grains with extended surface. Presence of loam in the mixture caused almost $50 \%$ increase in the specific surface area and the respective increase in sorption capacity. The results obtained in the study confirmed the expected sorption properties of the materials by demonstrating the similarity to natural sorbents such as clay.

${ }^{2}$ d.b. - dry basis. 


\subsection{BATCH STATIC SORPTION}

Based on Eq. (3), the authors calculated adsorption capacities of all metal ions in all mixtures studied (Table 5).

Table 5

Adsorption capacities [mg/g] of studied mixtures towards heavy metals (contact time $24 \mathrm{~h}$ )

\begin{tabular}{|c|c|c|c|c|c|c|c|c|c|c|c|}
\hline \multirow{3}{*}{ Mixture } & \multirow{3}{*}{$\begin{array}{c}c_{0} \\
{\left[\mathrm{mg} / \mathrm{dm}^{3}\right]}\end{array}$} & \multicolumn{10}{|c|}{ Adsorption capacity $\left(q_{e}\right)^{\mathrm{a}}$} \\
\hline & & \multicolumn{2}{|c|}{$\mathrm{Zn}^{2+}$} & \multicolumn{2}{|c|}{$\mathrm{Cd}^{2+}$} & \multicolumn{2}{|c|}{$\mathrm{Ni}^{2+}$} & \multicolumn{2}{|c|}{$\mathrm{Co}^{2+}$} & \multirow{2}{*}{\begin{tabular}{|c|}
$\mathrm{Cr}^{3+}$ \\
$\mathrm{CrCl}_{3}$ \\
\end{tabular}} & \multirow{2}{*}{$\begin{array}{c}\mathrm{Pb}^{2+} \\
\mathrm{PbNO}_{3}\end{array}$} \\
\hline & & $\mathrm{ZnCl}_{2}$ & $\mathrm{ZnSO}_{4}$ & $\mathrm{CdCl}_{2}$ & $\mathrm{CdSO}_{4}$ & $\mathrm{NiCl}_{2}$ & $\mathrm{NiSO}_{4}$ & $\mathrm{CoCl} 2$ & $\mathrm{CoSO}_{4}$ & & \\
\hline \multirow{11}{*}{ MPKI } & 0.1 & - & - & - & - & - & - & $<$ & $<$ & - & - \\
\hline & 0.5 & - & - & - & - & - & - & $<$ & $<$ & - & - \\
\hline & 1.0 & - & - & - & - & - & - & $<$ & $<$ & - & - \\
\hline & 5.0 & - & - & 0.0249 & 0.0249 & $<$ & $<$ & $<$ & $<$ & - & - \\
\hline & 10.0 & $<$ & $<$ & 0.0498 & 0.0498 & $<$ & $<$ & $<$ & $<$ & 0.0476 & $<$ \\
\hline & 50.0 & $<$ & $<$ & 0.2497 & 0.2497 & $<$ & $<$ & - & - & 0.2486 & $<$ \\
\hline & 100.0 & $<$ & $<$ & - & - & - & - & 0.4999 & 0.4999 & 0.4946 & $<$ \\
\hline & 150.0 & - & - & 0.7488 & 0.7488 & 0.7433 & $<$ & - & - & - & - \\
\hline & 200.0 & 0.9996 & 0.9995 & 0.9983 & 0.9982 & 0.9895 & $<$ & - & - & 0.9947 & 0.9997 \\
\hline & 500.0 & 2.4988 & 2.4932 & 2.4950 & 2.4948 & 2.4992 & 2.4991 & - & - & 2.4946 & 2.4994 \\
\hline & 1000.0 & 3.4188 & 2.9963 & - & - & - & - & - & - & 4.9996 & 4.9995 \\
\hline \multirow{11}{*}{ MPLI } & 0.1 & - & - & - & - & - & - & $<$ & $<$ & - & - \\
\hline & 0.5 & - & - & - & - & - & - & $<$ & $<$ & - & - \\
\hline & 1.0 & - & - & - & - & - & - & $<$ & $<$ & - & - \\
\hline & 5.0 & - & - & 0.0250 & 0.0250 & $<$ & $<$ & $<$ & $<$ & - & - \\
\hline & 10.0 & $<$ & $<$ & 0.0500 & 0.0500 & $<$ & $<$ & $<$ & $<$ & $<$ & $<$ \\
\hline & 50.0 & $<$ & $<$ & 0.2499 & 0.2498 & $<$ & $<$ & - & - & $<$ & $<$ \\
\hline & 100.0 & $<$ & $<$ & - & - & - & - & 0.4999 & 0.4999 & 0.4985 & $<$ \\
\hline & 150.0 & - & - & \begin{tabular}{|l|}
0.7499 \\
\end{tabular} & 0.7498 & \begin{tabular}{|l|l|}
0.7500 \\
\end{tabular} & \begin{tabular}{|l|}
0.7500 \\
\end{tabular} & - & - & - & - \\
\hline & 200.0 & 0.9996 & 0.9995 & 0.9998 & 0.9997 & \begin{tabular}{|l|}
0.9999 \\
\end{tabular} & \begin{tabular}{|l|}
0.9999 \\
\end{tabular} & - & - & 0.9958 & $<$ \\
\hline & 500.0 & 2.4960 & 2.4957 & 2.4999 & 2.5000 & 2.4997 & 2.4996 & - & - & 2.4951 & 2.4995 \\
\hline & 1000.0 & 4.9990 & 4.9990 & - & - & - & - & - & - & 4.9819 & 4.9998 \\
\hline \multirow{11}{*}{ MPD } & 0.1 & - & - & - & - & - & - & $<$ & $<$ & - & - \\
\hline & 0.5 & - & - & - & - & - & - & $<$ & $<$ & - & - \\
\hline & 1.0 & - & - & - & - & - & - & $<$ & $<$ & - & - \\
\hline & 5.0 & - & - & 0.0250 & 0.0250 & $<$ & $<$ & $<$ & $<$ & - & - \\
\hline & 10.0 & $<$ & $<$ & 0.0500 & 0.0500 & $<$ & $<$ & $<$ & $<$ & 0.0497 & $<$ \\
\hline & 50.0 & 0.2497 & 0.2496 & 0.2499 & 0.2499 & $<$ & $<$ & - & - & $<$ & $<$ \\
\hline & 100.0 & \begin{tabular}{|l|}
0.4997 \\
\end{tabular} & 0.4994 & - & - & - & - & 0.4967 & 0.4968 & 0.4954 & $<$ \\
\hline & 150.0 & - & - & 0.7499 & 0.7499 & 0.7500 & $<$ & - & - & - & - \\
\hline & 200.0 & 0.9996 & \begin{tabular}{|l}
0.9995 \\
\end{tabular} & 0.9997 & 0.9996 & \begin{tabular}{|l|}
0.9998 \\
\end{tabular} & \begin{tabular}{|l|}
0.9999 \\
\end{tabular} & - & - & 0.9883 & $<$ \\
\hline & 500.0 & 2.4969 & 2.4967 & 2.4888 & 2.4902 & 2.4433 & 2.4509 & - & - & 2.4874 & 2.4996 \\
\hline & 1000.0 & 4.9426 & 4.9553 & - & - & - & - & - & - & 4.9980 & 4.9991 \\
\hline
\end{tabular}

a $<$ below detection range: $<0.005$ for $\mathrm{Zn},<0.001$ for $\mathrm{Ni},<0.001$ for $\mathrm{Co},<0.02$ for $\mathrm{Cr},<0.03$ for $\mathrm{Pb}$. 
Figures 3-8 illustrate the effect of the type of ions of the metals studied and their initial content on the effectiveness of sorption process (Eq. (4)). For metals in which the equilibrium concentration was below the detection threshold (Table 5) we assumed that their removal is $100 \%$. Since sorption of metals is closely related to $\mathrm{pH}$ of the environment $[13,14]$, in the figures, $\mathrm{pH}$ values determined for eluates after sorption are also presented.

Regardless of the initial concentrations of salts (except for $c_{0}=1000 \mathrm{mg} / \mathrm{dm}^{3}$ ) as well as of the type of the adsorbent mixture, the removal of zinc was higher than $99 \%$. However, removal of zinc as sulfate was less effective than as zinc chloride. Regarding the concentration of $1000 \mathrm{mg} / \mathrm{dm}^{3}$ for the mixture MPKI, a decrease in sorption ability to the level of $68.4 \%$ for $\mathrm{Zn}^{2+}$ in $\mathrm{ZnCl}_{2}$ and $59.9 \%$ for $\mathrm{Zn}^{2+}$ in $\mathrm{ZnSO}_{4}$ occurred (Fig. 3). A very high percentage of sorption (over $99 \%$ ) was maintained in the mixture MPLI, while in the mixture MPD, it decreased by $1 \%$ for $\mathrm{Zn}^{2+}$ in $\mathrm{ZnCl}_{2}$. Furthermore, the decrease in sorption ability of MPKI mixture was accompanied by a substantial decrease in $\mathrm{pH}$ to ca. 6. Slightly lower decrease occurred in the mixture MPD and the mixture MPLI exhibited stabilization of $\mathrm{pH}$, regardless of the initial concentration ( $\mathrm{pH}$ ranged from 10.1 to 12.48).

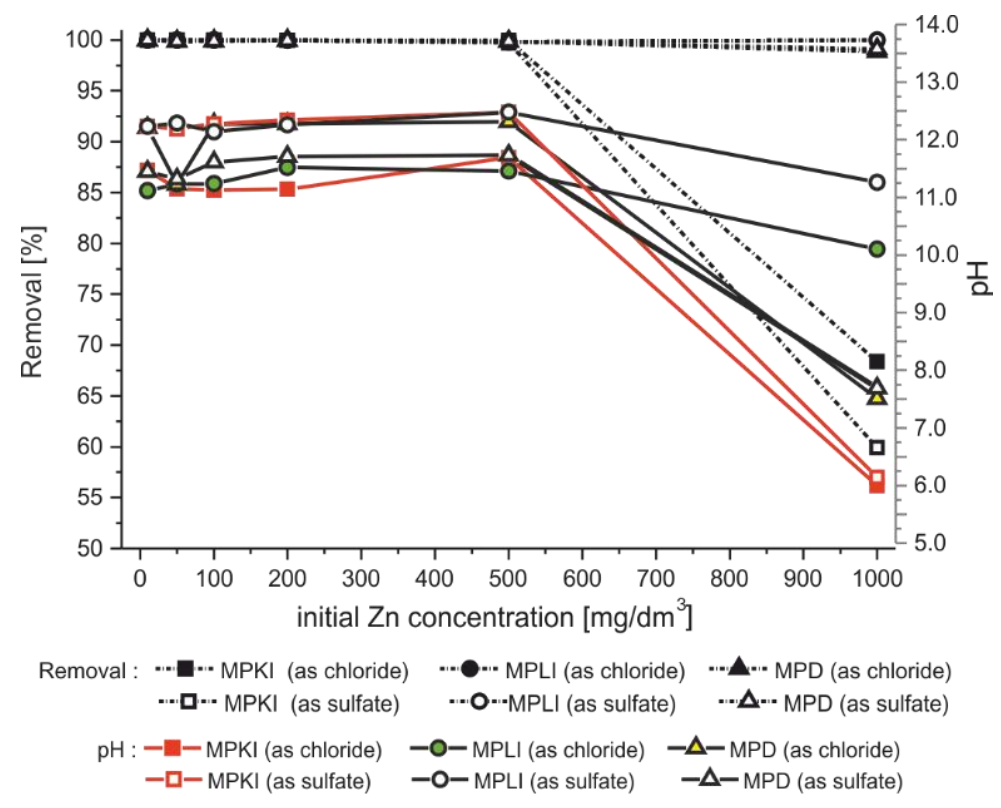

Fig. 3. Effect of initial concentration on removal of zinc

(as chlorides and sulfates) and $\mathrm{pH}$ of the solution; adsorbent dose $200 \mathrm{~g} / \mathrm{dm}^{3}$, agitation rate $150 \mathrm{rpm}$, contact time $24 \mathrm{~h}$, temperature $298 \mathrm{~K}$, initial $\mathrm{pH} 4$ ) 


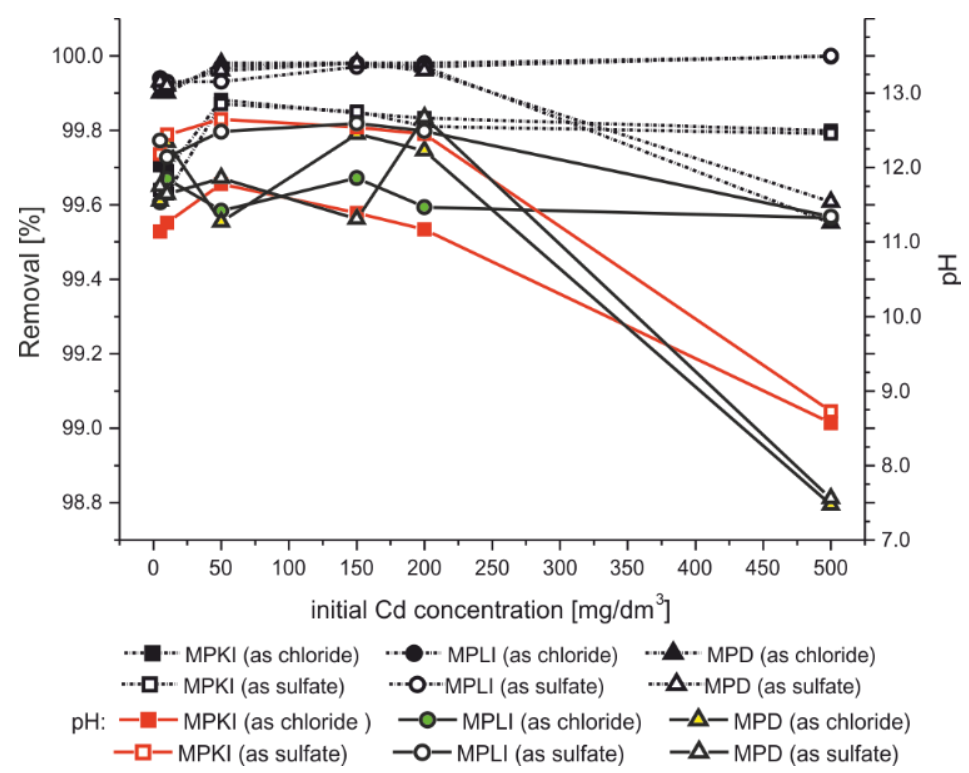

Fig. 4. Effect of initial concentration on removal of cadmium and $\mathrm{pH}$ of the solution; adsorbent dose $-200 \mathrm{~g} / \mathrm{dm}^{3}$, agitation rate $150 \mathrm{rpm}$, contact time $24 \mathrm{~h}$, temperature $298 \mathrm{~K}$, initial pH 4

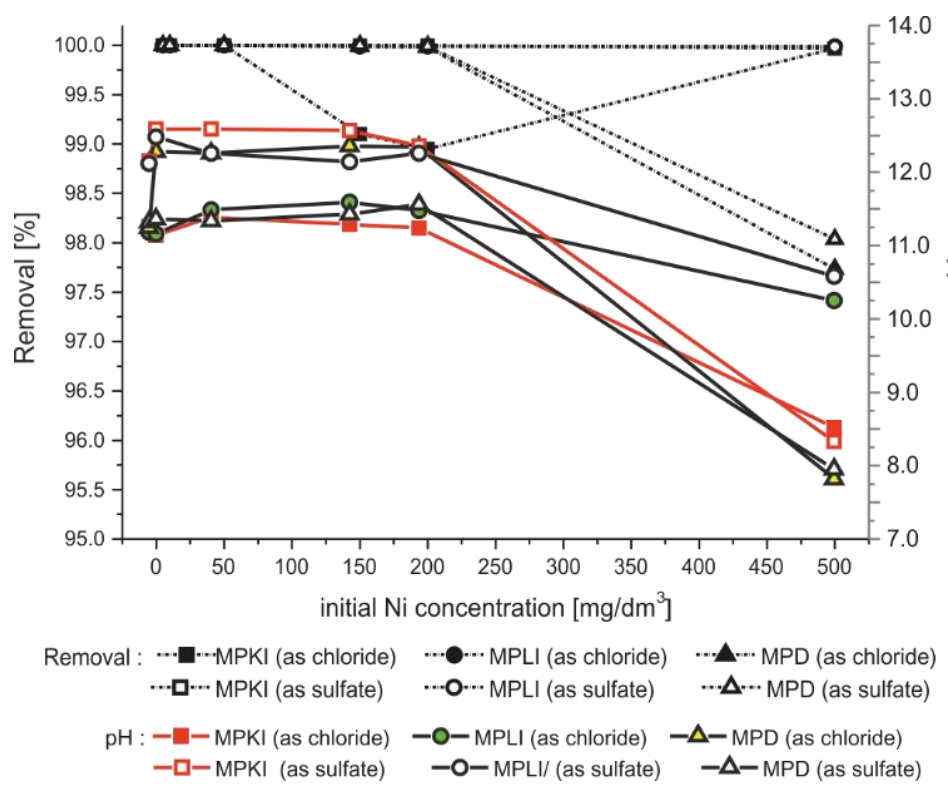

Fig. 5. Effect of initial concentration on removal of nickel and $\mathrm{pH}$ of the solution; adsorbent dose $200 \mathrm{~g} / \mathrm{dm}^{3}$, agitation rate $150 \mathrm{rpm}$, contact time $24 \mathrm{~h}$, temperature $298 \mathrm{~K}$, initial pH 4 
The mixtures studied, regardless of the initial concentration, exhibited cadmium ions removal rate at the level of 99\% (Fig. 4). Only the mixture MPKI was characterized by a reduced (by ca. $0.3 \%$ ) sorption ability. The most stable conditions of sorption of cadmium were observed in the mixture MPLI. With initial concentration of $500 \mathrm{mg} / \mathrm{dm}^{3}$ in the cases of MPKI and MPD, a reduction in $\mathrm{pH}$ value within the range of 7.5-8.7 was observed.

As shown in Figure 5, all the mixtures removed nickel ions in 100\%, when the initial concentration amounted up to $50 \mathrm{mg} / \mathrm{dm}^{3}$. In the case of nickel sulfate, this metal was removed totally up to initial concentration of $200 \mathrm{mg} / \mathrm{dm}^{3}$ and $150 \mathrm{mg} / \mathrm{dm}^{3}$ respectively for mixture MPKI and MPD. The mixtures MPKI and MPD demonstrated higher capability of removal of nickel ions in the form of sulfates. No effect of the type of salt ions on sorption ability was observed for the mixture MPLI. Maximum decrease of this ability in all the types of mixtures was found for the initial concentration of $500 \mathrm{mg} / \mathrm{dm}^{3}$. Changes in $\mathrm{pH}$ values are analogous as for the previously discussed metals.

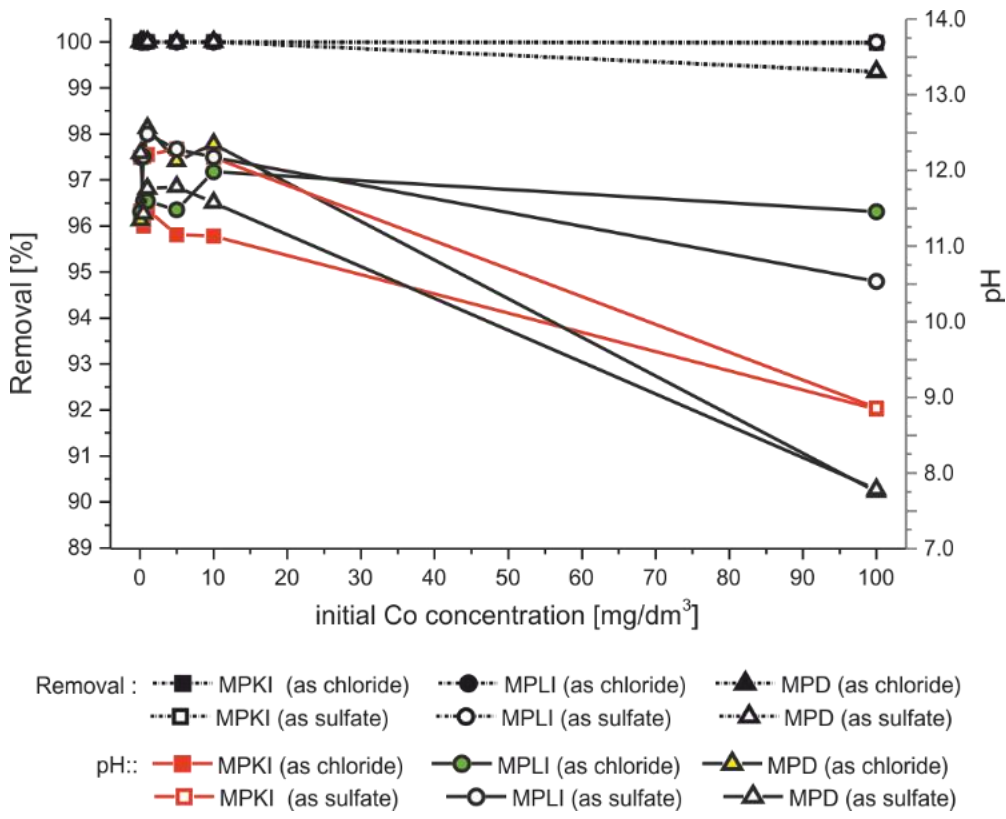

Fig. 6. Effect of initial concentration on removal of cobalt and $\mathrm{pH}$ of the solution; adsorbent dose $200 \mathrm{~g} / \mathrm{dm}^{3}$, agitation rate $150 \mathrm{rpm}$, contact time $24 \mathrm{~h}$, temperature $298 \mathrm{~K}$, initial pH 4 


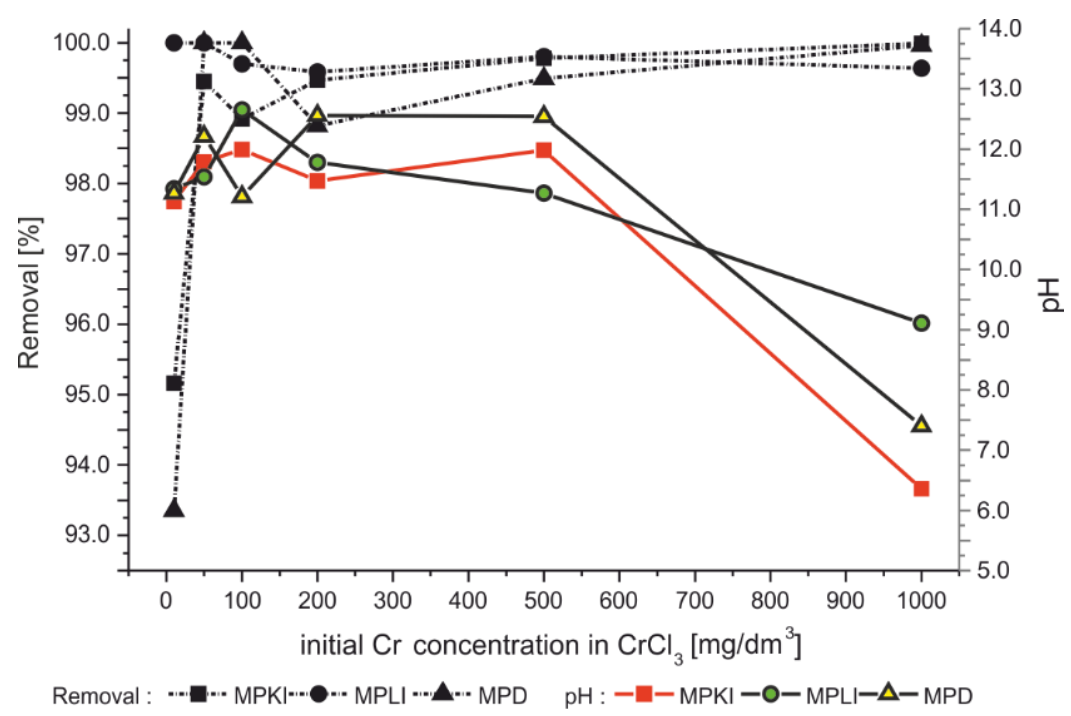

Fig. 7. Effect of initial concentration on removal of chrome and $\mathrm{pH}$ of the solution; adsorbent dose $200 \mathrm{~g} / \mathrm{dm}^{3}$, agitation rate $150 \mathrm{rpm}$, contact time $24 \mathrm{~h}$, temperature $298 \mathrm{~K}$, initial pH 4

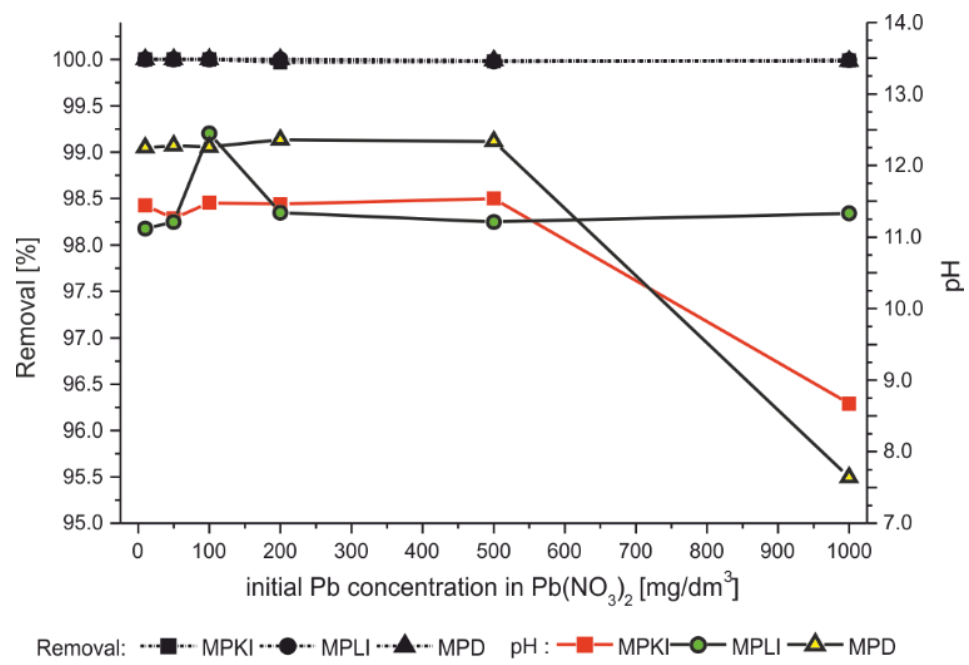

Fig. 8. Effect of initial concentration on removal of lead and $\mathrm{pH}$ of the solution; adsorbent dose $200 \mathrm{~g} / \mathrm{dm}^{3}$, agitation rate $150 \mathrm{rpm}$, contact time $24 \mathrm{~h}$, temperature $298 \mathrm{~K}$, initial pH 4

With initial concentration of up to $10 \mathrm{mg} / \mathrm{dm}^{3}$ for all the mixtures, regardless of the type of salt ions, sorption percentage for cobalt was maximum (concentration below the analyser detection threshold) (Fig. 6). At the concentration of $100 \mathrm{mg} / \mathrm{dm}^{3}$, it decreased 
to $99.9 \%$ for the mixtures MPKI and MPLI and to $99.3 \%$ for the mixture MPD. This relationship is connected with $\mathrm{pH}$ value with the biggest decrease observed also for the mixture MPD. The mixture MPLI had also biggest ability to neutralize changes in $\mathrm{pH}$ occurring in the sorption process.

Chromium ion removal for the mixtures MPKI and MPD was the lowest for the lowest initial concentrations studied $\left(10 \mathrm{mg} / \mathrm{dm}^{3}\right.$, Fig. 7). These mixtures showed different pattern: the sorption percentage increases for the highest initial concentrations. Changes in $\mathrm{pH}$ were similar to those for other metals. Similar results have been observed by other authors [16]. For instance, Kelleher et al. [17] reported at low initial concentrations film diffusion effects contributing to limiting the overall rate of adsorption while at higher initial $\mathrm{Cr}^{3+}$ concentrations pore diffusion became more important. These authors also shown that adsorption process was best described by the Langmuir model.

The mixture MPLI showed the highest stabilization of $\mathrm{pH}$. In all the cases, the percentage of lead removal was over $99.9 \%$, whereas the decrease in its value with the increase in initial concentration is insignificant (Fig. 8). The mixtures MPKI and MPD exhibited total removal of lead from the solution of the initial concentration of $200 \mathrm{mg} / \mathrm{dm}^{3}$.

Fly ash as an additive in the mixtures was found to be effective for the removal of heavy metals from aqueous solution, for example wastewater. The difference in the removal of metals may be due to mineralogical compositions of mixtures as well as kinds of heavy metal used in the tests [18], their ionic sizes, stability of bonds between heavy metals and adsorbent [7].

The main mechanism of the removal of heavy metals in aqueous solution consists of the following processes: a) surface precipitation - co-precipitation of insoluble hydroxides of heavy metals insoluble hydroxides form successive layers on the sorbent surface, $b$ ) bulk solution precipitation; c) ion exchange, d) adsorption. The factor which decides which mechanisms dominate is $\mathrm{pH}$ of the solution [19]. The mechanism of precipitation of metal hydroxides describe equations:

$$
\begin{gathered}
\mathrm{M}(\mathrm{OH})_{2}(\mathrm{~s}) \leftrightarrow \mathrm{M}^{2+}+2 \mathrm{OH}^{-} \\
\mathrm{M}^{2+}+\mathrm{OH}^{-} \leftrightarrow \mathrm{M}(\mathrm{OH})^{+} \\
\mathrm{M}^{2+}+2 \mathrm{OH}^{-} \leftrightarrow \mathrm{M}(\mathrm{OH})_{2} \\
\mathrm{M}^{2+}+3 \mathrm{OH}^{-} \leftrightarrow \mathrm{M}(\mathrm{OH})_{3}^{-} \\
\mathrm{M}^{2+}+4 \mathrm{OH}^{-} \leftrightarrow \mathrm{M}(\mathrm{OH})_{4}^{2-}
\end{gathered}
$$


The initial metal concentration in solution significantly affects the removal of tested metals [20]. Similarly as in this study, in most cases the increase of initial metal concentration resulted in an increase of the adsorption capacity (Table 5) and a decrease of the removal efficiency (Figs. 3-8). According to Arief et al. [21] the effect described depends on a combination of the following factors: the ability of surface functional groups to bonding metal ions (especially at high concentrations) and the availability of specific surface functional groups.

Another important factor influencing adsorption efficiency as well as mobility of heavy metals in matrix is $\mathrm{pH}[6,7]$. The alkaline nature of fly ash makes it a good neutralising agent (Figs. 3-8). For almost all mixtures (with the exception of a mixture of MPKI and $\mathrm{Zn}$ and $\mathrm{Pb}$ ) regardless of the initial concentration of metal, final $\mathrm{pH}$ was higher than 7 and sorption of metal cations increased upon increasing $\mathrm{pH}$. The heavy metal ion adsorption data were correlated with the isotherm models of Langmuir (Eqs. (5) and (6)) and Freundlich (Eqs. (7) and (8)). Table 6 presents the constants for the analysed models for the data which obtained high correlation coefficient. For other cases, the results of the analysis revealed that they cannot be described with the models tested or they lack sufficient amount of data for the analysis (the cases where removal percentage was at the level of $100 \%$ and no metals studied were found in eluates).

Isotherm parameters and correlation coefficients calculated based on experimental data

\begin{tabular}{|l|l|c|c|c|c|c|c|}
\hline \multirow{3}{*}{ Mixture } & \multirow{2}{*}{ Salt } & \multicolumn{2}{|c|}{ Freundlich isotherm } & \multicolumn{3}{c|}{ Langmuir isotherm } \\
\cline { 3 - 8 } & & $\begin{array}{c}K_{F} \\
{\left[\mathrm{dm}^{3} / \mathrm{mg}\right]}\end{array}$ & $1 / n$ & $R^{2}$ & $\begin{array}{c}K_{L} \\
{\left[\mathrm{dm}^{3} / \mathrm{mg}\right]}\end{array}$ & $\begin{array}{c}q_{m} \\
{[\mathrm{mg} / \mathrm{g}]}\end{array}$ & $R^{2}$ \\
\hline \multirow{2}{*}{ MPKI } & $\mathrm{ZnCl}_{2}$ & 2.06 & 0.09 & 0.9342 & 6.86 & 3.50 & 0.9876 \\
\cline { 2 - 8 } & $\mathrm{ZnSO}_{4}$ & 1.84 & 0.09 & 0.9420 & 4.63 & 2.96 & 0.9995 \\
\hline \multirow{2}{*}{ MPLI } & $\mathrm{ZnCl}_{2}$ & - & - & - & 19.11 & 3.66 & 0.7140 \\
\cline { 2 - 8 } & $\mathrm{ZnSO}_{4}$ & - & - & - & 18.42 & 3.58 & 0.6981 \\
\hline \multirow{2}{*}{ MPD } & $\mathrm{ZnCl}_{2}$ & 2.18 & 0.34 & 0.9765 & 1.64 & 5.17 & 0.9952 \\
\cline { 2 - 8 } & $\mathrm{ZnSO}_{4}$ & 2.14 & 0.39 & 0.9731 & 1.28 & 5.40 & 0.9935 \\
\hline \multirow{2}{*}{ MPKI } & $\mathrm{CdCl}_{2}$ & 2.49 & 0.84 & 0.9990 & 0.38 & 9.00 & 0.9993 \\
\cline { 2 - 8 } & $\mathrm{CdSO}_{4}$ & 2.40 & 0.86 & 0.9984 & 0.34 & 9.57 & 0.9986 \\
\hline \multirow{2}{*}{ MPD } & $\mathrm{CdCl}_{2}$ & 1.89 & 0.36 & 0.9644 & 10.72 & 2.60 & 0.9923 \\
\cline { 2 - 8 } & $\mathrm{CdSO}_{4}$ & 1.96 & 0.38 & 0.9702 & 9.18 & 2.63 & 0.9914 \\
\hline \multirow{2}{*}{ MPLI } & $\mathrm{NiCl}_{2}$ & - & - & - & 155.41 & 2.77 & 0.99659 \\
\cline { 2 - 8 } & $\mathrm{NiSO}_{4}$ & - & - & - & 347.54 & 2.55 & 0.95758 \\
\hline \multirow{2}{*}{ MPD } & $\mathrm{NiCl}_{2}$ & 1.68 & 0.15 & 0.9996 & 21.92 & 2.42 & 0.94265 \\
\cline { 2 - 8 } & $\mathrm{NiSO}_{4}$ & 1.94 & 0.10 & 0.9997 & 453.26 & 2.45 & 0.9993 \\
\hline MPLI & $\mathrm{CrCl}_{3}$ & 1.81 & 0.80 & 0.9729 & 0.16 & 13.65 & 0.9751 \\
\hline MPKI & \multirow{2}{*}{$\left.\mathrm{Pb}_{2} \mathrm{NO}_{3}\right)_{2}$} & - & - & - & 2.64 & 14.95 & 0.7373 \\
\cline { 3 - 8 } MPD & - & - & - & 2.76 & 14.78 & 0.9996 \\
\hline
\end{tabular}


Higher values of the correlation coefficient $\left(R^{2}\right)$ corresponded to better adjustment of the theoretical model to the experimental isotherm [22]. Data summarized in Table 6 shown that both models can describe the experimental data. However, analysis of the data contained in the Table 6 reveals that the mixture MPLI does not exhibit good match to the Freundlich model for zinc and nickel ions. Similar effect was observed for mixtures MPKI and MPD in the case of removal of lead ions. For other analysed metals, this mixture is characterized by better match to the Langmuir model. In conclusion, one can assume that in all the mixtures for which the match to either of the isotherms analysed could be calculated, the coefficients of this match were at a very high level.

\subsection{SPECIATION ANALYSIS}

Due to a different character of the phenomena which might occur during the process of removal of metals on the mixtures studied, the authors carried out the speciation analysis of the mixture MPLI for zinc ion sorption at its initial concentration of $100 \mathrm{mg} / \mathrm{dm}^{3}$. The procedure of speciation was carried out for the sorbent both before and after sorption. MPLI was chosen due to its high capability of removal of all the analysed ions, $\mathrm{Zn}$ due to its high mobility in the environment. The results are presented in Fig. 9.

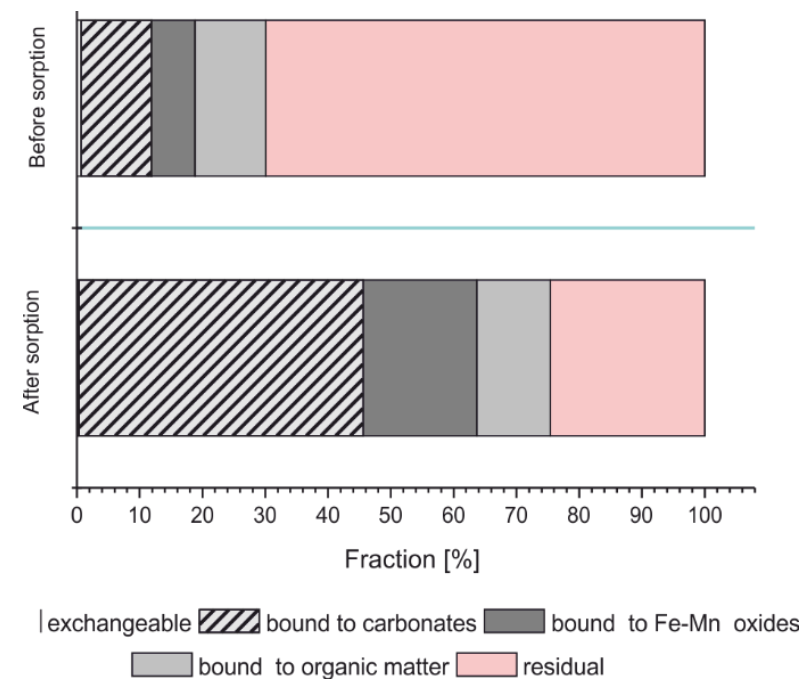

Fig. 9. Speciation of $\mathrm{Zn}$ in mixture (MPLI) after and before sorption; adsorbent dose $200 \mathrm{~g} / \mathrm{dm}^{3}$, agitation rate $150 \mathrm{rpm}$, contact time $24 \mathrm{~h}$, temperature $298 \mathrm{~K}$, initial $\mathrm{pH} 4$, initial metal concentration in $\mathrm{ZnCl}_{2} 100 \mathrm{mg} / \mathrm{dm}^{3}$

According to Jun Yao et al. [23], among the five fractions, the exchangeable fraction and the fractions bound with carbonates and $\mathrm{Fe}-\mathrm{Mn}$ oxides are unstable and susceptible to release, whereas the fractions connected with the organic matter and sulfides are regarded relatively stable and with low bioavailability [24]. The results obtained in the 
study confirmed the expected distribution of zinc in individual fractions which resulted from alkaline character of the components of the mixture and the content of clay minerals included in both clay and coal sludge. Zinc in MPLI mixture before sorption is present mainly in the residual/silicate fraction (69.9\%) that includes the forms contained in the crystalline network of primary and secondary minerals included in composition of individual components of the mixture. Fractions II and IV contain comparable amounts of metals at the level of $11.2 \%$, whereas the easiest leachable exchangeable fraction contains barely $0.7 \%$ of zinc. Reaction of the mixture with the solution containing $100 \mathrm{mg} / \mathrm{dm}^{3}$ zinc ions caused a change in the distribution of metal content in individual fractions. The results of sorption carried out by the batch method for the analysed mixture showed total removal of zinc ions from the solution (equilibrium concentration below the analyser detection threshold). Material after sorption is characterized by the increase in the amount of zinc mainly in the carbonate fraction and connected with $\mathrm{Fe}$ and $\mathrm{Mn}$ oxides, whereas a noticeable loss of zinc was connected with the crystalline fraction. The zinc amount present in the fraction connected with the organic matter and sulfates remained at a comparable percentage. Despite finding that bounding metal mainly by the unstable fractions (II and III), the alkaline character of the mixture proposed for construction of the separation screen should effectively prevent from the desorption of metal as a result of reduction in $\mathrm{pH}$ of the environment.

\subsection{ANALYSIS OF SORBENT GRAIN COMPOSITION}

The results of grain size analysis of the mixtures used in the study before and after sorption are presented in Figs. 10-12.

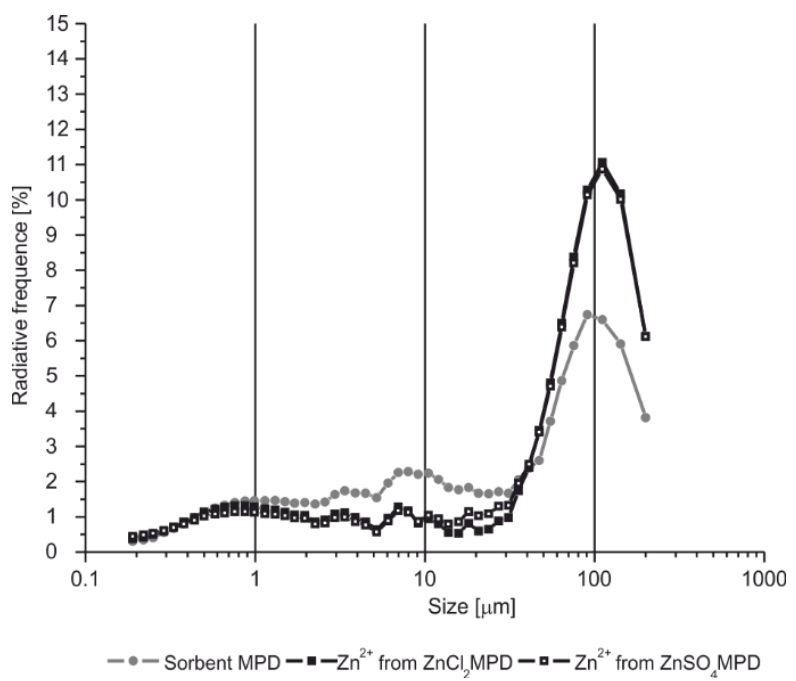

Fig. 10. Distribution of grain size in MPD sample before sorption and after sorption of zinc ions with initial concentration $c_{0}$ of $200 \mathrm{mg} / \mathrm{dm}^{3}$ 


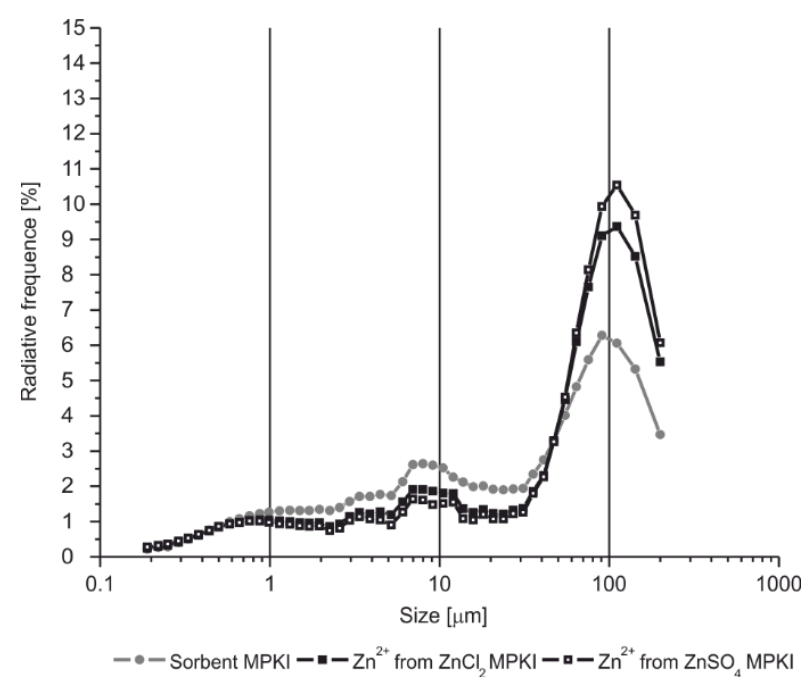

Fig. 11. Distribution of grain size in MPKI sample before sorption and after sorption of zinc ions with initial concentration $c_{0}$ of $200 \mathrm{mg} / \mathrm{dm}^{3}$

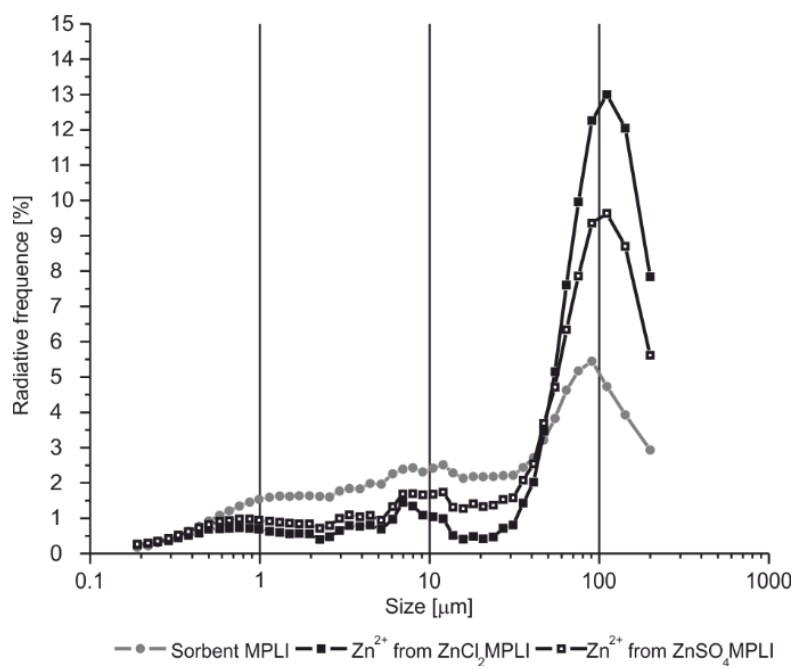

Fig. 12. Distribution of grain size in MPLI sample before sorption and after sorption of zinc ions with initial concentration $c_{0}$ of $200 \mathrm{mg} / \mathrm{dm}^{3}$

The analysis was carried out in order to verify the hypothesis that the phenomena occurring during removal of metals from the solution in contact with sorbent might consist, among other things, in precipitation of new mineral phases as a result of chemical reactions. The new mineral phases which appeared in grain distribution might have manifested themselves in development of fine grain size fractions. Hence the material used for analysis of sorbent before and after sorption was sieved until the fraction of 
$<200 \mu \mathrm{m}$ was obtained. With regard to grains with size of $0.1-1 \mu \mathrm{m}$, no changes in their content in the material after sorption were observed for mixtures MPD and MPKI. A decrease in the content of $1 \mu \mathrm{m}$ grains was observed only for the mixture MPLI after sorption. An interesting pattern can be observed in the curves of grain distribution for the mixtures studied: a higher content of $100 \mu \mathrm{m}$ grains was found after sorption. For the MPD mixture, the type of the sorbed zinc ions did not affect this phenomenon. Considering other mixtures, the effect of the type of ions was found, with the greatest increase in the content of $100 \mu \mathrm{m}$ grains observed in the mixture MPLI for chloride ions and sulfate ions in MPKI. Therefore, the proposed hypothesis was not verified, although based on the analysis of the phenomena occurring in fly ashes used as additives to cement [25], it can be assumed that the reactions in the materials are of pozzolanic reaction character. As a result of reaction with water, calcium oxide present in the ashes is transformed into calcium hydroxide, which then dissociates. The greater amounts of $\mathrm{Ca}^{2+}$ released with considerable presence of silicon ions $\mathrm{H}_{3} \mathrm{SiO}_{4}^{-}$and aluminium ions $\mathrm{H}_{4} \mathrm{AlO}_{4}^{-}$ in the solutions create hydrates which cover the crystalline phase of the material and increase the grain size.

\section{CONCLUSIONS}

- The mixture of coal dust, fly ash from fluidized bed boilers and clays (MPLI) points to the highest sorption capacity of heavy metals compared to mixture of ash from combustion in conventional boilers, coal dust and clays (MPKI) as well as mixture of coal dust and bottom ash (MPD).

- The highest stability of $\mathrm{pH}$ during sorption, regardless of the initial concentration of metal ions and the type of salts, was observed for the mixture MPLI. $\mathrm{pH}$ decreased only for the maximum initial concentration $\left(1000 \mathrm{mg} / \mathrm{dm}^{3}\right.$ for $\mathrm{Zn}^{2+}, \mathrm{Cr}^{3+}$ and $\mathrm{Pb}^{2+}, 500 \mathrm{mg} / \mathrm{dm}^{3}$ for $\mathrm{Cd}^{2+}$ and $\mathrm{Ni}^{2+}, 100 \mathrm{mg} / \mathrm{dm}^{3}$ for $\mathrm{Co}^{2+}$ ). This effect is desirable in the light of the opportunities of using this material for construction of separation screens since it is able to prevent the process of discharging ions of heavy metals to the environment as a result of acidification.

- All the mixtures studied are characterized by high ability to remove of heavy metals at the level of over $99 \%$, even with high contents of metal ions and the differences are practically negligible. The only exception is the mixture MPKI, where the percentage of sorption of zinc ions at initial concentration higher than $500 \mathrm{mg} / \mathrm{dm}^{3}$ decreases to the level of $60-70 \%$.

- Speciation analysis demonstrated that the most of zinc is bound in unstable phases: carbonate phase and $\mathrm{Fe}$ and Mn oxides. However, the ability of the mixture MPLI to stabilize $\mathrm{pH}$ confirmed in the batch test guarantees the stability of the metal in these phases. 
- The phenomenon of the increase of mineral aggregates during sorption processes is desirable since the bigger grains improve separation properties of the material through narrowing the intergranular space and therefore allowing migration of the solutions through the material that creates the separation screen in the landfill sites.

\section{ACKNOWLEDGEMENTS}

This research was supported by the research project of the National Centre Science No. N N506 157940 and BS/PB-401-304/11.

\section{REFERENCES}

[1] Nhan C.T., Graydon J.W., KIRK D.W., Utilizing coal fly ash as a landfill barrier material, Waste Manage., 1996, 16, 587.

[2] Sobik-Szoltysek J., BieŃ J.B., MilcZareK M., Analysis of filtration coefficient in the aspect of opportunities for application of alternative materials for building separation screens in landfills, Annu. Set Environ. Prot., 2013, 15, 1393 (in Polish).

[3] Allen A., Containment landfills: the myth of sustainability, J. Eng. Geol., 2001, 60, 3.

[4] Piecuch T., Piekarski J., MalatyŃska G., Filtration of mixtures forming compressible sediments, Annu. Set Environ. Prot., 2013, 15, 39.

[5] Claisse P.A., Ganjian E., Transport processes for harmful species through concrete barriers made with mineral wastes, Const. Build. Mater., 2009, 23 (5), 1837.

[6] Fijalkowski K., Kacprzak M., Grobelak A., PlaceK A., The influence of selected soil parameters on the mobility of heavy metals in soils, Eng. Prot. Environ., 2012, 15, 81.

[7] Violante A., Cozzolino V., Perelomov L., Caporale A.G., Pigna M., Mobility and bioavailability of heavy metals and metalloids in soil environments, J. Soil Sci. Plant Nutr., 2010, 10 (3), 268.

[8] PN-B-04481:1988P, Building soils. Laboratory tests.

[9] Gawriuczenkow I., Poznan's clay as a geologic separation screens in municipal landfill sites, Pol. Geol. Rev., 2005, 53 (8), 691 (in Polish).

[10] Chen H., Zhao J., Dai G., Silkworm exuviae. A new non-conventional and low-cost adsorbent for removal of methylene blue from aqueous solutions, J. Hazard. Mater., 2011, 186 (2), 1320.

[11] Chowdhury S., Mishra R., Saha P., Kushwaha P., Adsorption thermodynamics, kinetics and isosteric heat of adsorption of malachite green onto chemically modified rice husk, Desalination, 2011, 265 (1), 159.

[12] Tessier A., CAmpbell P.G.C., Bisson M., Sequential extraction procedure for the speciation of particulate trace metals, Anal. Chem., 1979, 51, 844.

[13] Santamarina J.C., Klein K.A., Wang Y.H., Prencke E., Specific surface: determination and relevance, Can. Geotech. J., 2002, 39 (1), 233.

[14] BAILEy S.E., Olin T.J., BRICKA R.M., AdRIAN D.D., A review of potentially low-cost sorbents for heavy metals, Water Res., 1999, 33 (11), 2469.

[15] HongZHU Q., The effects of change in fineness of fly ash on air-entraining concrete, Open Civil Eng. J., 2011, 5, 124.

[16] Wang S., Wu H., Environmental-benign utilisation of fly ash as low-cost adsorbents, J. Hazard. Mater., 2006, 136 (3), 482.

[17] Kelleher B.P., O’CAllaghan M.N., Leahy M.J., O'DwYeR T.F., LEAhy J.J., The use of fly ash from the combustion of poultry litter for the adsorption of chromium(III) from aqueous solution, J. Chem. Technol. Biotechnol., 2002, 77, 1212. 
[18] Sheta A.S., Falatah A.M., Al-Sewailem M.S., Khaled E.M., Sallam A.S.H., Sorption characteristics of zinc and iron by natural zeolite and bentonite, Micropor. Mesopor. Mater., 2003, 61 (1), 127.

[19] ERol M., KÜÇÜKBAYRAK S., ERSOY-MeriçBOyU A., Ulubaș T., Removal of $\mathrm{Cu}^{2+}$ and $\mathrm{Pb}^{2+}$ in aqueous solutions by fly ash, Energ. Convers. Manage., 2005, 46 (7), 1319.

[20] Wu D., SuI Y., HE S., WANG X., Li C., Kong H., Removal of trivalent chromium from aqueous solution by zeolite synthesized from coal fly ash, J. Hazard. Mater., 2008, 155 (3), 415.

[21] ARIEF V.O., Trilestari K., Sunarso J., IndRaswati N., ISMADJI S., Recent progress on biosorption of heavy metals from liquids using low cost biosorbents: characterization, biosorption parameters and mechanism studies, Clean Soil, Air, Water, 2008, 36 (12), 937.

[22] GuPTA V.K., SuHAS, Application of low-cost adsorbents for dye removal. A review, J. Environ. Manage., 2009, 90 (8), 2313.

[23] Yao J., Li W.B., Kong Q.N., Wu Y.Y., He R., Shen D.S., Content, mobility and transfer behavior of heavy metals in MSWI bottom ash in Zhejiang province, China, Fuel, 2010, 89, 616.

[24] KaCPRZAK M., GrobelaK A., Grosser A., Prasad M.N.V., Efficacy of biosolids in assisted phytostabilization of metalliferous acidic sandy soils with five grass species, Int. J. Phytoremediat., 2014, 16 (6), 593.

[25] Mertens G., Snellings R., Van Balen K., Bicer-Simsir B., Verlooy P., Elsen J., Pozzolanic reactions of common natural zeolites with lime and parameters affecting their reactivity, $\mathrm{Cem}$. Concr. Res., 2009, 39 (3), 233. 